\title{
Review of Laparoscopy Activities at the Gynecology and Obstetrics Department of the Military Hospital of Ouakam
}

\author{
MM Niang*, B Diop, A Mbodji, Yfo Gaye, Aa Diouf and Ct Cisse \\ Gyneacology and Obstetrics Department, Institute of Social Hygiene, Sénégal
}

Submission: March 08, 2018; Published: May 04, 2018

*Corresponding author: Mouhamadou Mansour NIANG, Cheikh Anta Diop University of Dakar, Sénégal, Email: mansniang@hotmail.com

\section{Introduction}

Since the introduction of laparoscopy in surgery in the 1940s by Raoul Palmer, many teams have developed its applications in various specialties around the world. This rise in endoscopic surgery is linked to the many advantages it offers compared to conventional surgery in terms of morbidity, perioperative mortality and cost. Developing in developed countries over the last twenty years, progress in laparoscopy is still insufficient in Africa. Where it is mainly performed for diagnostic purposes or for tubal sterilization. According to MBAYE, laparoscopy accounted for $14.37 \%$ of gynecological operative activity at the Gynecological and Obstetric Clinic of the Hospital Aristide le Dantec in the early 2000s. At the Military Hospital of Ouakam (MHO), first cases of laparoscopy begin in November 2014.

After two years of activities, we carried out this study whose objectives were to evaluate the frequency of gynecological laparoscopy at the MHO, to draw up the epidemiological profile of the operated patients, to specify the operative indications, the per and post complications. -operations and the future of patients.

\section{Patients and methods}

This was a retrospective and descriptive study of all laparoscopic surgical procedures performed at the Gynecology and Obstetrics Department of the Military Hospital of Ouakam over a 28-month period from November 1,2014 to March 31, 2017. all indications for surgery for presumed benign uterine-adnexal pathology, laparoscopy was the first-line approach. We studied the following parameters: the frequency, the characteristics of the patients, the data of the surgical intervention (indication of operation, type of anesthesia, first, abdomino-pelvic exploration, gestures made, intraoperative incidents and duration of the surgical intervention) and the postoperative course.

The data was entered with the Excel 2013 software and analyzed with the Epi Info version 7 software.

\section{Results}

\section{Frequency}

During the study period, we recorded 361 gynecological procedures. Of these, 115 were performed laparoscopically, a frequency of $31.9 \%$. It was essentially a scheduled surgery (92.2\%). The acts carried out urgently concerned $7.8 \%$ of our sample.

\section{Socio-demographic characteristics of patients}

The average age of the patients was 33.8 years with extremes of 13 and 64 years. The majority of patients (63.5\%) were between 21 and 40 years of age (Table 1). The majority of patients were nulliparous $(65.2 \%)$ and a history of surgery was found in 12 patients $(10.4 \%)$. There were 5 caesareans $(41.1 \%)$, 2 ovarian cystectomies (16.7\%), 2 courses of ectopic pregnancy (16.7\%), tubal ligation (8.3\%), one myomectomy $(8.3 \%)$ and herniated disc (8.3\%).

Table 1: Distribution according to the age of patients $(\mathrm{N}=115)$.

\begin{tabular}{|c|c|c|}
\hline Age (years) & Number & Frequency (\%) \\
\hline 13 à 20 & 11 & \\
\hline 21 à 30 & 48 & \\
\hline 31 à 40 & 25 & \\
\hline 41 à 50 & 22 & \\
\hline 51 à 60 & 3 & 100 \\
\hline 61 et plus & 115 & \\
\hline Total & 6 & \\
\hline
\end{tabular}

\section{Data of the surgical intervention}

During the study period, we performed 31 diagnostic laparoscopies (27\%) and 84 operative laparoscopies (73\%). We also performed 10 emergency laparoscopies (8.7\%) including 8 ectopic pregnancies (UGI) and 2 appendix twists. Surgical indications are summarized in Table 2. 
Table 2: Distribution according to operative indications $(\mathrm{N}=115)$.

\begin{tabular}{|c|c|c|}
\hline Diagnostic & Number & Frequency (\%) \\
\hline Abcès tubo-ovarien & 1 & 0,9 \\
\hline Dysplasie cervicale sévère & 4 & 3,5 \\
\hline Nodule d'endométriose & 1 & 0,9 \\
\hline Grossesse extra-utérine & 8 & 6,9 \\
\hline Hydrosalpinx & 5 & 4,3 \\
\hline Hyperplasie de l'endomètre & 8 & 6,9 \\
\hline Kyste ovarien organique & 42 & 36,5 \\
\hline Myome utérin & 3 & 2,6 \\
\hline Utérus pseudo-unicorne & 1 & 0,9 \\
\hline Obstruction tubaire & 30 & 26,1 \\
\hline Prolapsus génital & 4 & 3,5 \\
\hline Syndrôme des ovaries & 6 & 5,2 \\
\hline micropolykystiques & 2 & 1,7 \\
\hline Torsion d'annexe & 115 & 100 \\
\hline Total & & \\
\hline
\end{tabular}

Operative procedures were dominated by methylene blue (26.4\%) and adhesiolysis (20.7\%). We also performed ovarian cystectomy in 31 cases $(16.8 \%)$, total hysterectomy associated with adnexectomy in 23 patients (12.9\%) and ovarian drilling in 13 patients $(7.3 \%)$ (Table 3$)$.

Table 3: Distribution according to operative procedures performed in patients who underwent laparoscopy at the HMO between 2014 and $2017(\mathrm{~N}=115)$.

\begin{tabular}{|c|c|c|}
\hline Operative procedures & Number & Frequency (\%) \\
\hline Adhésiolyse & 37 & 20,7 \\
\hline Annexectomie & 8 & 4,4 \\
\hline Drilling ovarien & 13 & 7,3 \\
\hline Exérèse de nodule d'endométriose & 10 & 5,6 \\
\hline Epreuve au bleu de Méthylène & 47 & 26,4 \\
\hline Expression tubaire & 2 & 1,1 \\
\hline Hydroflotation & 2 & 1,1 \\
\hline $\begin{array}{c}\text { Hystérectomie } \\
\text { totale+annexectomie }\end{array}$ & 23 & 16,8 \\
\hline Kystectomie ovarienne & 30 & 3,4 \\
\hline Néosalpingostomie & 6 & 0,6 \\
\hline Résection d'une corne utérine \\
rudimentaire
\end{tabular}

Only one conversion was recorded in our series, ie $6.3 \%$. It was motivated by the existence of uterine myomatosis probably responsible for a tubal obstruction.

We recorded three bleeding events (2.6\%). It was an injury of the left umbilical artery during the introduction of the supra pubic trocar and two difficulties of hemostasis of the uterine artery. In all cases, hemostasis was obtained by coagulation with the bipolar clamp.

The duration of the procedure was between 35 and 65 minutes for diagnostic laparoscopies (average of 47 minutes), and between 40 and 140 minutes for laparoscopic surgery (average of 78.8 minutes).

\section{Postoperative data}

We recorded 2 postoperative complications: suppuration of the umbilical opening and intestinal obstruction by incarceration of a small loop at the opening of the umbilical trocar.

\section{Discussion}

\section{Frequency}

During the study period, laparoscopy was the primary approach used for $31.9 \%$ of surgeries at the Ouakam Military Hospital. This rate is higher than those reported by MBAYE [1] at the Gynecological and Obstetric Clinic of the University Hospital Center of Dakar in 2009 and CISSE [2] at Roi Baudouin Hospital in 2011, which were respectively $14.37 \%$ and $13 \%$. LE [3] in Ivory Coast recorded a rate of $21 \%$. This difference could be explained by the extension, in our practice, of indications because of the progressive increase in the number of practitioners trained in this technique. However, this rate is low compared to those found in Western series where laparoscopy is the first-line approach for almost all surgical procedures in Gynecology [4]. Indeed, according to BRUHAT [5], 70\% of gynecological surgery was achievable by laparoscopy in 1994. CHAPRON, meanwhile, [4] estimates that more than $80 \%$ of interventions for benign adnexal pathology (GEU, ovarian cyst, etc. .) are made by this route. Two main explanations could be given at this still low rate that we recorded. On the one hand, it is the high cost of the endoscopy column and the instruments used that our structures have difficulty renewing in the event of failure and, on the other hand, the still insufficient number of medical and especially paramedical staff trained in laparoscopy. Indeed, in our structure, the material was acquired as part of a donation and only one gynecologist is trained in laparoscopy. No operating room nurse has received specific training in endoscopic surgery and the technical services are not used to maintenance of the equipment. To improve the frequency of laparoscopic surgical procedures, it would be necessary to obtain a second column of spare endoscopy with the necessary instruments to overcome the technical failures that sometimes force us to interrupt the activity, Train the other gynecologist surgeons to this path first, the operating room nurses to the use and maintenance of the equipment as well as the technical services staff for their maintenance.

\section{Operating data}

In our series, we recorded $73 \%$ operative laparoscopies. FAVRE [6] found a similar result in his study. On the other hand, our level is higher than that reported by MBAYE which was of the order of $55.1 \%$ of laparoscopic procedures including $35.1 \%$ of adhesiolyses. This evolution proves that laparoscopy occupies an increasingly important place in our surgical practice.

The ovarian organic cyst was the main indication for laparoscopic surgery (36.5\%), followed by tubal infertility 
(26.1\%). In most African series, tubal infertility was the main indication for laparoscopy with rates of $77.5 \%$ in the MBAYE series [1] and 76.3\% for MBOUDOU in Cameroon [7]. Long practiced for diagnostic purposes or for performing minor surgical procedures, major laparoscopy is more and more common in our developing countries, as evidenced by the $21.2 \%$ rate of assisted hysterectomies we have recorded. However, compared to Western series, our laparoscopic rate is still low.

In our series, 10 patients underwent emergency laparoscopy $(8.7 \%)$. These were 8 cases of USG and two schedule twists. This rate is low compared to those found in other African series [8]. The reasons given were the unavailability of emergency laparoscopic equipment, the shortage of human resources trained in this technique and the high frequency of ruptured GEUs associated with haemodynamic instability, which contraindicate the laparoscopic approach.

We also performed 23 total hysterectomies (12.9\%). It was associated with an adnexectomy in all patients. The choice of the approach for a hysterectomy is not the subject of any consensus and depends on different parameters: training and surgeon's habit, patient's wishes, anatomical considerations, antecedents surgical and pathology [9]. The vaginal route is the path of choice [10-13]. It is beneficial compared to laparotomy for reducing the average length of postoperative stay, lower analgesic consumption, early resumption of transit and activity. It would also be less expensive than laparoscopy [14]. However, this approach has some limitations or contraindications. These include large, myomatous uteri beyond the umbilicus, narrow vulvar orifice, fixed uteri, and deep endometriosis [15]. In these situations, coel preparation would be an interesting alternative. Also, the adnexectomy would be easier by coelio-prepared way compared to the vaginal way in case of annexial pathology.

\section{Per and post-operative complications}

We recorded 3 intraoperative haemorrhage complications, intestinal obstruction and vaginal suppuration at a rate of $4.3 \%$. This rate is relatively low compared to the series of CISSE [2] at Roi Baudouin Hospital which recorded a conversion rate of $6.3 \%$ and a post-operative complication in $4.7 \%$ of cases. Despite these numerous advantages, the coelio-prepared pathway could expose the patient to a risk of haemorrhage and urinary lesions, especially in the case of polymyomatous uterus enclosed in the Douglas cul-de-sac that make access to the uterine pedicles difficult. . These situations are often encountered in our developing countries or, because of the delay in consultation and diagnosis, we often take care of these bulky polymyomatous uteri beyond the umbilicus. In these situations, laparotomy would be the first line of choice and would reduce the risk of complication.

There were no deaths in our series, unlike MBAYE [1], which had one death. In the literature, lethality varies between 3 and 8 deaths per 100,000 laparoscopies $[7,16]$ and depends on the experience and training of the teams as well as the progress of anesthesia and resuscitation [8].

\section{Conclusion}

The results recorded in our study show the feasibility of both diagnostic and therapeutic laparoscopy in our resource-poor countries. However, the limited number of gynecologist surgeons trained in this technique, the unavailability of endoscopy equipment in most public facilities and their lack of maintenance are all obstacles to the expansion of this surgical approach in our regions.

\section{References}

1. Jean-Marie Okwo-Bele (2015) Together we can close the immunization gap. World Health Organization, Geneva, Switzerland.

2. Lambert P-H, Liu M, Siegrist CA (2005) Can successful vaccines teach us how to induce efficient protective immune responses? Nature medicine 11: 54-62.

3. Chiappini E, Stival A, Galli L (2013) Pertussis re-emergence in the postvaccination era. BMC infectious diseases 13(1): 151.

4. Winter K, Harriman K, Zipprich J (2012) California pertussis epidemic. The Journal of pediatrics 161(6): 1091-1096.

5. Raya BA, Bamberger E, Almog M (2015) Immunization of pregnant women against pertussis: the effect of timing on antibody avidity. Vaccine 33(16): 1948-1952.

6. Hashemi SH, Zamani M, Mamani M (2014) Seroprevalence of Bordetella pertussis antibody in pregnant women in Iran. Journal of research in health sciences 14(2): 128-131.

7. Za'tsev E, Krasnoproshina L, Astakhova T (2010) Monitoring of antibodies against diphtheria, tetanus and pertussis in pregnant women. Zhurnal mikrobiologii, epidemiologii, i immunobiologii (1): 32-35.

8. Diez-Domingo J, Ballester A, Baldó J-Ma (2004) Incidence of pertussis in persons $\leq 15$ years of age in Valencia, Spain: seroprevalence of antibodies to pertussis toxin (PT) in children, adolescents and adults. Journal of Infection 49(3): 242-247.

9. Okada K, Ueda K, Morokuma K (2004) Seroepidemiologic study on pertussis, diphtheria, and tetanus in the Fukuoka area of southern Japan: seroprevalence among persons $0-80$ years old and vaccination program. Japanese journal of infectious diseases 57(2): 67-71.

10. Sočan M, Prosenc K, Vegnuti M (2006) Seroprevalence of IgG antibodies to pertussis toxin in the Slovene population. Wiener klinische Wochenschrift 118(11-12): 336-340.

11. Wilder-Smith A, Ng S, Earnest A, Earnest A (2006) Seroepidemiology of pertussis in the adult population of Singapore. Annals-Academy of Medicine Singapore 35(11): 780.

12. Amirthalingam G, Andrews N, Campbell H (2014) Effectiveness of maternal pertussis vaccination in England: an observational study. The Lancet 384(9953): 1521-1528.

13. Nikbin VS, Shahcheraghi F, Lotfi (2013) Comparison of culture and realtime PCR for detection of Bordetella pertussis isolated from patients in Iran. Iran J Microbiol 5(3): 209-214.

14. Badamchi A, Papizadeh M (2017) Comparative Phylogeny of the Genus Bordetella Using Sequence Analysis of $16 \mathrm{~S}$ rRNA and ompA Genes. Journal of Medical Bacteriology 6(3,4): 1-3. 
This work is licensed under Creative Commons Attribution 4.0 License DOI: 10.19080/JGWH.2018.09.555765
Your next submission with Juniper Publishers will reach you the below assets

- Quality Editorial service

- Swift Peer Review

- Reprints availability

- E-prints Service

- Manuscript Podcast for convenient understanding

- Global attainment for your research

- Manuscript accessibility in different formats ( Pdf, E-pub, Full Text, Audio)

- Unceasing customer service

Track the below URL for one-step submission https://juniperpublishers.com/online-submission.php 